\title{
Analisis Penerapan Konsep 5S di Bagian Proses Maintenance PT. Traktor Nusantara
}

\author{
Vera Devani ${ }^{1}$, Ade Fitra ${ }^{2}$ \\ ${ }^{1,2}$ Jurusan Teknik Industri, Fakultas Sains dan Teknologi, UIN Sultan Syarif Kasim Riau \\ J1. HR. Soebrantas No. 155 Simpang Baru, Panam, Pekanbaru, 28293 \\ Email: veradevani@gmail.com
}

\begin{abstract}
ABSTRAK
Tujuan dari penelitian iniadalah untuk mengetahui persentase tanggapan positif dan negatif karyawan terhadap implementasi 5S, mengetahui masalah-masalah dalam penerapan $5 \mathrm{~S}$ pada bagian proses maintenance, serta untuk menentukan proses pengendalian dan tindak lanjut penerapan $5 \mathrm{~S}$ pada bagian proses maintenance di PT. Traktor Nusantara Pekanbaru. Metode yang digunakan dalam penelitian ini adalah Metode 5S. 5S adalah teknik untuk menjaga mutu lingkungan sebuah perusahaan atau institusi dengan cara mengembangkan keterorganisirannya, perlunya tempat kerja yang aman dan nyaman, pengelolaan tempat kerja, dan pentingnya peningkatan efisiensi dan produktifitas. Responden pada penelitian ini adalah seluruh mekanik yang bekerja pada bagian maintenance PT. Traktor Nusantara Pekanbaru. Hasil pengolahan data terhadap konsep 5S secara keseluruhan indikator, dapat diketahui bahwa rata-rata yaitu sebanyak 84,91\% responden memberikan tanggapan positif. Hal ini mengindikasikan bahwa pada umumnya mekanik PT. Traktor Nusantara sudah baik dalam memahami dan mengaplikasikan konsep 5S. Namun masih terdapat sekelompok mekanik yang memiliki respon negatif yaitu sebesar 15,08\%. Masalah-masalah dalam penerapan 5S, mekanik kurang optimal dalam hal menerapkan prinsip-prinsip Seiketsu (pemantapan). Untuk mengatasi hal tersebut perlu dilakukan pengkodean peralatan dan mengaruskan setiap karyawan untuk mengembalikan perlengkapan kerja yang sudah digunakan ketempat asal.
\end{abstract}

\section{Kata kunci : Ergonomi, 5S}

\section{Latar Belakang}

Perkembangan dunia industri manufaktur dan jasa semakin meningkat pesat dari waktu ke waktu sehingga setiap pelaku industri harus siap berkompetisi dan selalu meningkatkan kinerja yang dapat meningkatkan produktivitas. Masalah peningkatan produktivitas tidak dapat lepas dari faktor manusia yang dapat diamati, diteliti, dianalisa dan diperbaiki. Hal ini dilakukan sebagai usaha untuk mendapatkan alternatif cara kerja yang baik, efektif, dan efisien.

Lingkungan kerja yang tidak baik menyebabkan produktivitas manufaktur menjadi rendah sehingga akan berdampak pada kualitas produk yang dihasilkan. Target dan rencana produksi tidak dapat direalisasikan, bilamana unsur - unsur produktivitas yang meliputi kualitas, efisiensi, dan efektifitas bernilai rendah maka dengan sendirinya produktivitas perusahaan pun akan menjadi rendah.
PT. Traktor Nusantara merupakan perusahaan jasa yang bergerak dalam pendistribusian, penyewaan dan maintenance alat berat.

Pada saat ini kondisi lingkungan kerja PT. Traktor Nusantara sudah nyaman. Ruangan kerja yang bersih, pada bagian mesin, peralatan, dan lantai. Material-material yang akan diproses disusun dan tertata rapi, namun beberapa peralataan maintenance masih ada yang belum tersimpan dengan baik, sehingga tool sering hilang dan barang-barang yang tidak berguna sering ditemui di workshop. Mekanik pernah bermasalah dengan ketelitian dalam bekerja sehingga tidak efektif dalam proses maintenance. Hal ini karena salah satu upaya pendekatan yang digunakan dalam memperbaiki lingkungan kerja dengan pendekatan konsep $5 \mathrm{~S}$ belum optimal.

Menurut Osada, 2004, 5S diartikan: Seiri (Pemilihan), Seiton (Penataan), Seiso (Pembersihan), Seiketsu (Pemantapan) dan Shitsuke (Pembiasaan). Perusahaan ini sudah menerapkan konsep 5S, yang dinamakan dengan 5K yaitu 
Ketelitian, Kerapian, Kebersihan, Kesegaran dan Kedisiplinan.

Penelitian yang pernah dilakukan oleh Wiratmani, 2010. tentang Implementasi Metode 5S pada Divisi Gudang Barang Jadi. Berdasarkan hasil perancangan dan implementasi didapatkan penilaian yang cukup baik dalam lokasi gudang. Perubahan tersebut dapat dibuktikan dengan hasil perancangan layout setelah dilakukan pengimplementasian kondisi tata letak gudang menjadi lebih teratur, lebih rapi dan alur pergerakan menjadi lebih cepat dan memudahkan operator gudang dalam penyiapan purchase order yang datang dari costumer. Peningkatan hasil penilaian status dari red menjadi gold.

Purwanggono, dkk., 2014. melakukan peneltian tentang Analisis Faktor-Faktor yang Mempengaruhi Motivasi Karyawan dalam Menerapkan Budaya Kerja 5S. Berdasarkan hasil penelitian, diperoleh bahwa motivasi, komunikasi, pelatihan, reward and recognition, dan peran top management berpengaruh positif terhadap motivasi karyawan dalam menerapkan $5 \mathrm{~S}$, dan diketahui variabel peran top management $(b 4=0.313)$ adalah variabel yang memiliki pengaruhterbesar dibandingkan variabel lainnya.

Tujuan penelitian yang dilakukan adalah untuk menetukan persentase tanggapan positif dan negatif mekanik terhadap implementasi 5S, menentukan akar penyebab tidak berjalannya implementasi 5S serta nenentukan proses pengendalian dan tindak lanjut penerapan $5 \mathrm{~S}$ di Bagian Proses Maintenance di PT. Traktor Nusantara.

\section{Tinjauan Pustaka}

\section{Konsep Ergonomi}

Ergonomi berasal dari kata Yunani, yaitu ergos (bekerja) dan nomos (hukum alam). Dengan demikian ergonomi dapat diberi makna sebagai ilmu yang meneliti tentang perkaitan antara orang dengan lingkungan kerjanya. Menurut Bennet (1991) dikutip oleh Listiani (2010), ergonomi adalah ilmu penyesuaian peralatan dan perlengkapan kerja dengan kemampuan esensial manusia untuk memperoleh keluaran yang optimum. Menurut Suma'mur (1989) dikutip oleh Listiani (2010), ergonomi sebagai ilmu yang penerapannya berusaha untuk menserasikan pekerjaan dan lingkungan terhadap orang atau sebaliknya, dengan tujuan mencapai produktivitas dan efisiensi yang setinggi-tingginya melalui pemanfaatan faktor manusia seoptimal-optimalnya.

Dengan menerapkan ergonomi, diharapkan karyawan dapat mencapai prestasi kerja yang tinggi dengan disertai suasana kerja yang tenteram, aman dan nyaman. Penerapan ergonomi, dilakukan dalam bentuk pengaturan sikap, tata cara kerja dan perencanaan kerja yang tepat.

Manfaat penerapan ergonomi diterapkan di tempat kerja (Sedarmayanti, 1996 dikutip oleh Listiani, 2010) adalah:

1. Mengadakan perhatian terhadap kondisi tenaga

2. kerja.

3. Menciptakan sikap tubuh yang ergonomik.

4. Pembebanan kerja sesuai dengan kemampuan

5. pegawai.

6. Mengatur lingkungan kerja yang tepat.

7. Menilai dan mengatur organisasi kerja.

8. Meningkatkan kesehatan dan keselamatan kerja.

9. Memperbaiki kualitas produksi.

\section{Metode 5S}

Setiap pimpinan organisasi di Jepang sangat memahami bagaimana seharusnya tempat kerja dikelola dan bagaimana upaya untuk memberikan kesadaran agar para pegawai memelihara tempat kerjanya. Sebagaimana yang telah diulas pada latar belakang masalah, 5S merupakan singkatan dari Seiri, Seiton, Seiso, Seiketsu, dan Shitsuke yang dapat diterjemahkan menjadi 5R, yaitu Ringkas, Rapi, Resik, Rawat dan Rajin. Pada dasarnya 5S menyangkut kegiatan pengorganisasian tempat kerja dan kerumahtanggaan. Hal-hal ini berdampak langsung terhadap efisiensi, produktivitas, mutu dan keselamatan kerja. Program 5S dipandang sebagai dasar dari segala program peningkatan mutu dan produktvitas, sehingga suatu organisasi mampu mencapai sasaran dengan tingkat efisiensi dan efektivitas kerja yang tinggi

Housekeeping management atau yang lebih dikenal dikalangan industri dengan $5 \mathrm{~S}$ atau $5 \mathrm{R}$ terbukti sangat efektif meningkatkan kinerja perusahaan. Prinsip dari 5R menekankan pada perbaikan tempat kerja untuk menjadi lebih ringkas, rapi dan resik yang dilakukan dengan kegiatan rawat dan rajin secara menyeluruh. Penerapan $5 \mathrm{~S}$ ini akan memberikan dampak positif terhadap sikap kerja karyawan perusahaan yang akhirnya menjadikan karyawan lebih disiplin dan sistematis dalam melakukan pekerjaan. Selain itu, juga 
tumbuh rasa memiliki terhadap keberadaan perusahaan tempat mereka bekerja.

Metode 5S (Seiri, Seiton, Seiso Seiketsu, dan Shitsuke) ini pertama kali muncul pada tahun 1980 an yang digagas oleh Takashi Osada. Metode 5S merupakan sebuah metode yang dapat digunakan untuk tujuan menciptakan dan menjaga kualitas lingkungan kerja dalam organisasi.

Pengertian falsafah 5S yaitu (Gasperz, 2001 dikutip oleh Risma, 2008):

1. Seiri, yaitu menyisihkan barang yang tidak diperlukan dengan yang perlu atau menyisihkan dan membuang barang yang tidak perlu di tempat kerja.

2. Seiton (susun), yaitu menata alat-alat kerja yang digunakan dengan rapi dan benar-benar menghilangkan kegiatan mencari agar alat-alat dapat mudah ditemukan dengan cepat.

3. Seiso, yaitu memelihara kebersihan tempat kerja.

4. Seiketsu, yaitu mempertahankan seiri, seiton, dan seiso agar dapat berlangsung terusmenerus.

5. Shitsuke, yaitu sebagai suatu kedisiplinan dan benar-benar menjadi kebiasaan, sehingga pekerja terbiasa menaati peraturan dan diadakan penyuluhan terhadap pekerja untuk bekerja secara profesional.

Menurut Gurel, 2013 dikutip oleh Widianti, dkk., 2015, menekankan bahwa 5S juga bertujuan untuk menjaga lingkungan kerja tetap aman, bersih, nyaman dan kondusif. Bayo,dkk., 2010 dikutip oleh Widianti, dkk., 2015, menyatakan bahwa $5 \mathrm{~S}$ memiliki hubungan yang positif terhadap kualitas dan produktivitas.

Penerapan 5S harus memperhatikan konteks dan kebutuhan praktikal sebuah organisasi agar tujuan organisasi dapat tercapai. Penerapan metode 5S umumnya dilakukan di industri manufaktur. Namun seiring dengan kebutuhan, 5S juga diterapkan dibidang lain misalnya di laboratorium dan perhotelan. Walaupun penerapan 5S telah sukses, perusahaan masih harus fokus melakukan peningkatan terus-menerus karena dengan jalan inilah mutu bisa dicapai.

5S adalah teknik untuk menjaga mutu lingkungan sebuah perusahaan atau institusi dengan cara mengembang-kan keterorga-nisirannya. Teknik yang dimaksud ini melibatkan 5 langkah yang dikerjakan secara berurutan dan dapat dilakukan dimanapun selama 6 hingga 2 tahun atau sampai dengan penerapan secara menyeluruh (Listiani, 2010).
Manfaat penerapan 5S secara umum, akan menghasilkan berbagai manfaat bagi perusahaan, seperti (Suwondo, 2012):

1. Meningkatkan semangat kerja tim.

2. Tempat kerja yang lebih bersih, rapi dan teratur.

3. Lingkungan kerja yang lebih aman dan nyaman.

4. Pengunaan ruang kerja secara optimal.

5. Mempermudah pemeliharaan rutin.

6. Mengadakan standar kerja yang jelas.

7. Kendali persediaan yang lebih efektif.

8. Mengurangi biaya operasional.

9. Meningkatkan citra perusahaan.

10. Mengurangi keluhan pelanggan.

Pemeliharaan kualitas lingkungan tempat kerja yang baik akan dapat mengurangi potensi terjadinya "bencana" seperti kesulitan mencari dokumen penting, staff yang cedera karena tersandung, dan sebagainya. "Bencana" tersebut bisa jadi diakibatkan oleh ketidak rapian dan ketidak terorganisiran barang-barang di tempat kerja

2008):

Adapun tujuan dari 5S adalah (Risma,

1. Memberikan penyadaran kepada peserta tentang perlunya tempat kerja yang aman dan nyaman.

2. Memberikan pengetahuan kepada peserta tentang dasar pentingnya pengelolaan tempat kerja.

3. Memberikan penyadaran kepada peserta tentang pentingnya peningkatan efisiensi dan produktifitas.

Tujuan yang diharapkan dengan menerapkan 5S di perusahaan adalah sebagai berikut (Osada, 2004):

1. Keamanan

Hampir selama puluhan tahun, kedua kata pemilahan dan penataan menjadi ciri khas pada poster-poster dan surat kabar bahkan di perusahaan-perusahaan kecil. Karena pemilahan dan penataan sangat berperan besar di dalam masalah keamanan.

2. Tempat kerja yang rapi

Tempat kerja yang menerapkan $5 \mathrm{~S}$ dengan teliti tidak perlu terus-menerus membicarakan keamanan, dan kecelakaan industri yang dialaminya akan lebih sedikit ketimbang pabrik yang hanya mengutamakan peralatan dan prosedur yang sedemikian aman sehingga tidak mungkin gagal.

3. Efisiensi 
Para ahli diberbagai bidang seperti, juru masak, pelukis, tukang kayu, akan menggunakan peralatan yang baik dan memeliharanya. Mereka tahu bahwa waktu yang dipergunakan untuk memelihara peralatan tidak terbuang percuma, bahkan hal itu menghemat lebih banyak waktu.

4. Mutu

Elektronika dan mesin-mesin modern memerlukan tingkat presisi dan kebersihan yang sangat tinggi, untuk menghasilkan output yang baik. Berbagai gangguan yang kecil dapat berakibat terhadap penurunan mutu dari output yang dihasilkan.

5. Kemacetan

Pabrik yang tidak menerapkan 5S akan menghadapi berbagai masalah kemacetan mulai dari mesin yang disebabkan kotoran yang mengendap ataupun kemacetan dalam ingatan karyawan, harus disadari bahwa ingatan seseorang bias saja salah, maka daripada itu diperlukan berbagai petunjuk yang melengkapi

keterbatasan seorang manusia dalam menjalankan tugasnya.

Sasaran penerapan $5 \mathrm{~S}$ terhadap perusahan yaitu (Listiani, 2010) :

1. Mewujudkan tempat kerja yang nyaman dan pekerjaan yang menyenangkan.

2. Melatih karyawan agar mampu mandiri dalam mengelola pekerjaannya.

3. Meningkatkan disiplin dalam penggunaan standar.

4. Mewujudkan "Visual Factory".

5. Meningkatkan citra positif di mata pelanggan.

Apabila metode 5S diterapkan secara benar maka akan diperoleh dampak positif terhadap perusahan yaitu (Listiani, 2010) :

1. Setiap orang akan mampu menemukan masalah lebih cepat.

2. Setiap orang akan memberikan perhatian dan penekanan pada tahap perencanaan.

3. Mendukung cara berpikir yang berorientasi pada proses.

4. Setiap orang akan berkonsentrasi pada masalah-masalah yang lebih penting dan mendesak untuk diselesaikan.

5. Setiap orang akan berpartisipasi dalam membangun sistem yang baru.

6. Meminimumkan potensi terjadinya :

- Accident (kecelakaan kerja)

- Breakdown (gangguan kerusakan)

- Cost (biaya)
- Defect (produk cacat)

7. Meningkatkan efisiensi dan semangat kerja.

8. Organisasi yang siap mengikuti perubahan sesuai arahan startegi pimpinan.

\section{Metode Penelitian}

Penelitian ini menggunakan metode penelitian deskriptif analisis, yaitu suatu penelitian yang menggambarkan fenomena yang terjadi di lapangan kemudian dipadukan dengan hasil jawaban responden dan wawancara.

Kuesioner yang telah disusun disebarkan kepada 18 orang mekanik di Bagian Maintenance PT. Traktor Nusantara. Penyebaran kuesioner bertujuan untuk mengetahui apakah mekanik telah menerapkan konsep 5S secara baik. Indikator yang digunakan untuk pertanyaan kepada mekanik adalah sebagai berikut:

1. Seiri (pemilahan), terdiri dari 3 variabel pertanyaan

2. Seiton (penataan), terdiri dari 4 variabel pertanyaan

3. Seiso (pembersihan), terdiri dari 5 variabel pertanyaan

4. Seiketsu (pemantapan), terdiri dari 3 variabel pertanyaan

5. Shitsuke (pembiasaan atau pendisiplinan), terdiri dari 6 variabel pertanyaan

Setiap indikotor dibagi lagi atas beberapa variabel pertanyaan, dengan total pertanyaan 21 . Skala yang digunakan pada setiap pertanyaan adalah menggunakan skala Linkert, yaitu:

- $\quad$ Sangat setuju $=4$

- $\quad$ Setuju $=3$

- $\quad$ Kurang setuju $=2$

- $\quad$ Tidak setuju $=1$

Setelah kuesioner dibuat, maka akan dilakukan uji validitas dan realibilitas untuk mengetahui kuesioner layak untuk disebarkan kepada mekanik. Uji validitas dilakukan untuk mengetahui apakah alat ukur yang digunakan menghasilkan nilai yang sesuai dengan tujuan alat ukur tersebut. Uji validitas menggunakan rumus Bivariate Pearson (Korelasi Pearson Product Moment). Pengujian mengunakan uji dua sisi dengan taraf signifikansi 0,05 . Kriteria pengujian adalah jika $r$ hitung $\geq r$ tabel maka instrumen atau item-item pertanyaan berkorelasi signifikan terhadap skor total (dinyatakan valid) (Priyatno, 2010).

Uji realibilitas dilakukan untuk mengetahui sejauh mana hasil pengukuran 
kuesioner yang digunakan relatif konsisten bila dilakukan pengukuran dua kali atau lebih pada responden yang berbeda. Realibilitas kuesioner berkaitan dengan skor hasil pengukuran terbebas dari kesalahan pengukuran. Metode yang digunakan dalam uji reliabilitas adalah metode Cronbach's Alpha. Metode Cronbach's Alpha sangat cocok digunakan pada skor berbentuk skala atau skor rentangan. Pengujian reliabilitas menggunakan batasan: reliabilitas kurang dari 0,6 adalah kurang baik, sedangkan 0,7 dapat diterima dan diatas 0,8 adalah baik. (Priyatno, 2010).

\section{Hasil dan Pembahasan}

Rekapitulasi tanggapan dari 18 orang mekanik terhadap penerapan konsep $5 \mathrm{~S}$ dapat dilihat pada lampiran 1. Berdasarkan deskripsi jawaban responden kemudian dilakukan pembobotan untuk masing-masing pertanyaan. Jumlah pembobotan untuk masing-masing pernyataan berdasarkan skala Linkert adalah sebagai berikut:

\section{Jumlah Pembobotan $=$ \\ $($ frek.SS $x$ 4) $+($ frek.S $\times 3)+($ frek.KS $\times 2)+$ (frek.TS $x$ 1)}

Keterangan:

$\begin{array}{ll}\text { SS } & \text { : Sangat setuju } \\ \text { S } & \text { : Setuju } \\ \text { KS } & \text { : Kurang setuju } \\ \text { TS } & : \text { Tidak setuju }\end{array}$

Setelah dihitung bobot setiap pertanyaan, kemudian ditentukan peringkat jawaban responden berdasarkan tingkat respon tertinggi (Lampiran 2). Setelah dilakukan perangkingan, maka tahap berikutnya menganalisa lima peringkat terendah, dengan menggunakan diagram sebab akibat (Ishikawa Diagram).

Masalah pertama terdapat pada indikator keempat yaitu indikator Seiketsu (pemantapan): pertanyaan nomor 15 (pengembalian perlengkapan kerja yang sudah digunakan ke tempat asal pengambilan). Hal ini karena mekanik hanya memiliki respon positif sebesar $61,11 \%$, dan nilai pembobotan 54. Gambar berikut menyajikan akar penyebab permasalahan tersebut.

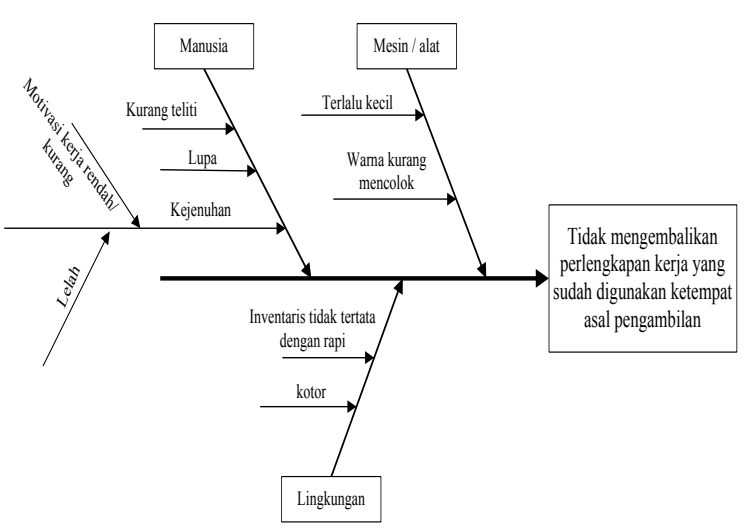

Gambar 1. Diagram Sebab Akibat Tidak Mengembalikan Tools

Masalah kedua terdapat pada indikator Shitsuke (Pendisiplinan): pertanyaan nomor 18 (mentaati setiap bentuk peraturan) kerja. Hal ini karena mekanik hanya memiliki respon positif sebesar 77,78\%, dan nilai pembobotan 55. Gambar berikut menyajikan akar penyebab permasalahan tersebut.

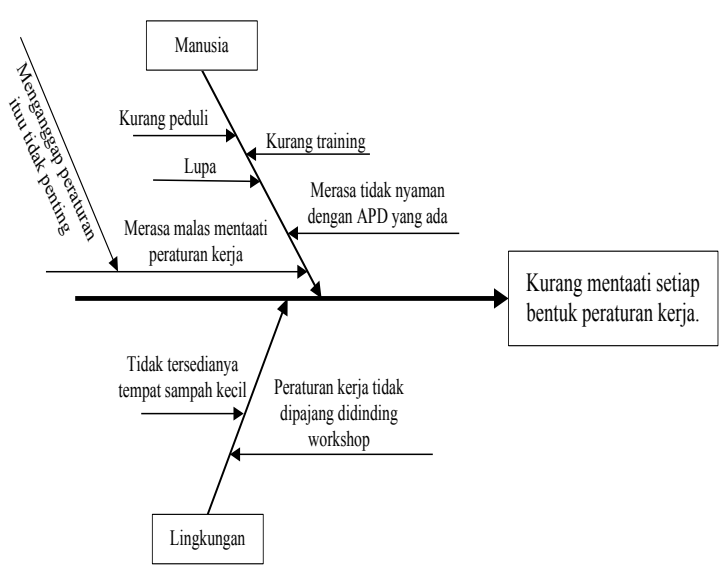

Gambar 2. Diagram Sebab Akibat Kurang Mentaati setiap Bentuk Peraturan Kerja

Masalah ketiga terdapat pada indikator kelima yaitu indikator Shitsuke (pendisiplinan): pertanyaan nomor 17 (memahami setiap peraturan kerja). Hal ini karena mekanik hanya memiliki respon positif sebesar $83,33 \%$ dan respon negatif sebesar $16,67 \%$, dan nilai pembobotan 55 . Gambar berikut menyajikan akar penyebab permasalahan tersebut. 


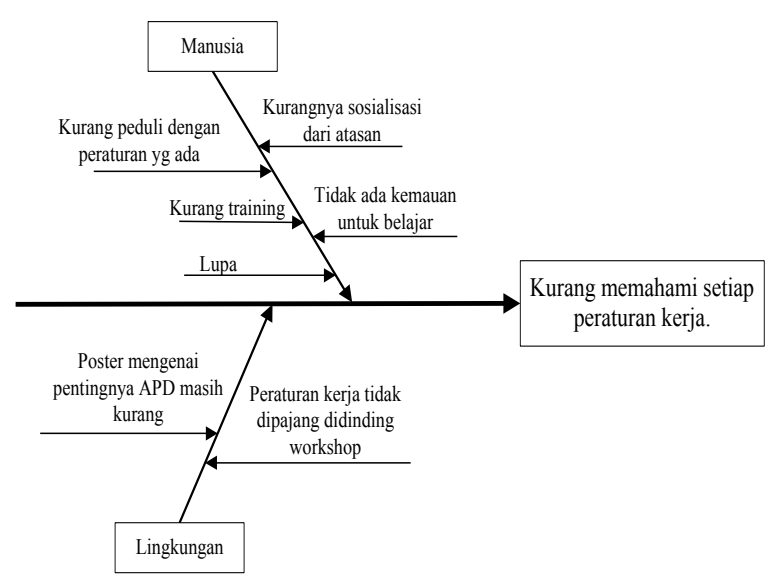

Gambar 3. Diagram Sebab Akibat Kurang Memahami Setiap Peraturan Kerja

Masalah keempat terdapat pada indikator kelima yaitu indikator Seiketsu (pemantapan): pertanyaan nomor 13 (setiap peralatan kerja (tools) disimpan dan dibedakan berdasarkan pengkodean). Hal ini karena mekanik hanya memiliki respon positif sebesar $83,33 \%$ dan respon negatif sebesar $16,67 \%$, dan nilai pembobotan 55 . Gambar berikut menyajikan akar penyebab permasalahan tersebut.

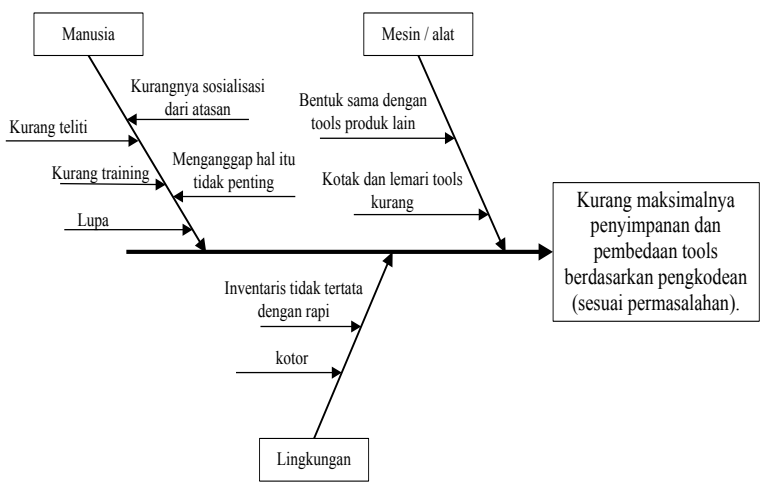

Gambar 4. Diagram Sebab Akibat Kurang Maksimalnya Penyimpanan dan Pembedaan Tools Berdasarkan Pengkodean (Sesuai Permasalahan)

Masalah kelima terdapat pada indikator kelima yaitu Seiketsu (pemantapan): pertanyaan nomor 21 (setiap rekan kerja saling mengingatkan untuk menciptakan suasana kerja yang tertib dan nyaman). Hal ini karena mekanik hanya memiliki respon positif sebesar $72,22 \%$ dan respon negatif sebesar $27,78 \%$, dan nilai pembobotan 56. Gambar berikut menyajikan akar penyebab permasalahan tersebut.

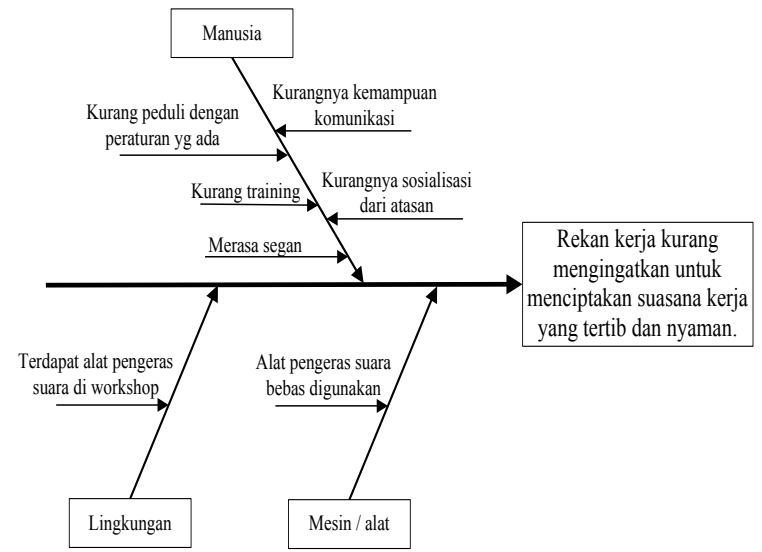

Gambar 5. Diagram Sebab Akibat Rekan

Kerja Kurang Mengingatkan untuk

Menciptakan Suasana Kerja yang Tertib dan

Nyaman

Hambatan yang dihadapi mekanik dalam penerapan konsep 5S diantaranya adalah:

1. Tingkat kesadaran mekanik dalam upaya menciptakan lingkungan kerja yang dapat memberi kemudahan untuk menyelesaikan pekerjaan, masih kurang.

Contoh:

Pada umumnya mekanik belum secara konsisten mentaati segala bentuk peraturan kerja dan memberikan contoh baik untuk menciptakan lingkungan kerja yang tertata.

2. Belum semua mekanik memiliki kemauan untuk bersama-sama menciptakan lingkungan kerja yang bersih, tertib, dan menyenangkan. Contoh:

Masih cukup banyak mekanik yang kurang peduli terhadap lingkungan kerja yang tidak tertata rapi, dan berdebu.

3. Faktor kebiasaan yang kurang baik di rumah, terbawa ke dalam lingkungan kerja. Contoh:

Tidak menyimpan kembali peralatan kerja (tools) di tempatnya semula, sehingga menyulitkan diri sendiri dan mekanik lain untuk menemukan peralatan tersebut pada saat membutuhkannya.

\section{Kesimpulan}

Berdasarkan dari tujuan penelitian maka disimpulkan sebagai berikut :

1. Berdasarkan pengolahan data terhadap penerapan konsep 5S, secara keseluruhan indikator, responden memberikan tanggapan 
positif sebesar $84,91 \%$ dan $15,08 \%$ memiliki respon negatif. Artinya, bahwa pada umumnya mekanik PT. Traktor Nusantara sudah baik dalam memahami dan mengaplikasikan konsep 5S

2. Masalah-masalah dalam penerapan konsep $5 \mathrm{~S}$ pada Bagian Proses Maintenance berdasarkan kelima indikator adalah :

a. Mekanik kesulitan dalam menemukan peralatan kerja dan kurangnya rasa nyaman saat bekerja akibat bunyi musik yang keras.

b. Masih ditemukannya sampah berupa kertas-kertas kecil, abu, puntung rokok, dan kayu-kayu kecil di lingkungan kerja.

c. Mekanik masih kurang memahami dan mentaati peraturan yang ada.

d. Mekanik masih belum maksimal dalam menjaga kebersihan lingkungan kerja maupun peralatan kerja.

3. Upaya peningkatan penerapan konsep $5 \mathrm{~S}$ sebagai proses pengendalian dan tindak lanjut penerapan $5 \mathrm{~S}$ diantaranya adalah:

a. Mekanik saling mengingatkan untuk menciptakan kenyamanan di lingkungan kerja.

b. Supervisor hendaknya melakukan evaluasi setiap hari terhadap kebersihan dan ketertiban lingkungan kerja.

c. Supervisor membuat peraturan atau slogan-slogan yang menggugah semangat untuk menciptakan lingkungan kerja yang nyaman.

d. Mengadakan lomba ketertiban, kebersihan, dan kedisiplinan bagi diri mekanik.

\section{Daftar Pustaka}

Listiani, T. Penerapan Konsep 5S dalam Upaya Menciptakan Lingkungan Kerja yang Ergonomis di STIA LAN Bandung. Jurnal Ilmu Administrasi. Vol. 7 No. 3 Hal 20142014, September 2010.

Osada T. 2004. Sikap Kerja 5S. Jakarta: PPM.

Priyatno, D. 2010. Paham Analisa Statistika Data dengan SPSS. Yogyakarta: MediaKom.

Purwanggono, dkk. Analisis Faktor-Faktor yang Mempengaruhi Motivasi Karyawan dalam Menerapkan Budaya Kerja 5S. Prosiding SNATIF Ke -1. 2014

Simanjuntak, R. A. dan Dian Hernita. Usulan Perbaikan Metode Kerja Berdasarkan
Micromotion Study dan Penerapan Metode 5S untuk Meningkatkan Produktifitas. Jurnal Teknologi, Vol. 1 No 2 Hal. 191-203. Desember 2008.

Suwondo, C. Penerapan Budaya Kerja Unggulan 5S (Seiri, Seiton, Seiso, Seiketsu, dan Shitsuke) di Indonesia. Jurnal Magister Manajemen. Vol. 1 No. 1 Hal. 29-48. April 2012.

Widianti, T., dkk. Implementasi 5S untuk Optimalisasi Keselamatan, Kesehatan, dan Performa Kerja. Prosiding Seminar Nasional Teknologi Pengelolaan Limbah XIII. 30 Desember 2015.

Wiratmani, E. Implementasi Metode 5S pada Divisi Gudang Barang Jadi. Jurnal Ilmiah Faktor Exacta. Vol. 3 No. 3 Hal. 268-286. September 2010. 


\section{Lampiran 1}

Tabel 1 Tanggapan Responden terhadap Penerapan Konsep 5S

\begin{tabular}{|c|c|c|c|c|c|c|c|c|c|c|c|}
\hline \multirow{3}{*}{ NO. } & \multirow{3}{*}{ INDIKATOR } & \multicolumn{8}{|c|}{ FREKUENSI JAWABAN RESPONDEN } & \multirow{2}{*}{\multicolumn{2}{|c|}{ JUMLAH }} \\
\hline & & \multicolumn{2}{|c|}{$\mathrm{SS}=4$} & \multicolumn{2}{|c|}{$\mathbf{S}=\mathbf{3}$} & \multicolumn{2}{|c|}{$\mathbf{K S}=\mathbf{2}$} & \multicolumn{2}{|c|}{$T S=1$} & & \\
\hline & & f & $\%$ & $\mathbf{f}$ & $\%$ & f & $\%$ & f & $\%$ & f & $\%$ \\
\hline 1. & Seiri (Pemilahan) & 24 & 133,3 & 26 & 144,4 & 4 & 22,22 & 0 & 0 & 54 & 300 \\
\hline 2. & Seiton (Penataan) & 26 & 144,4 & 38 & 211,1 & 7 & 38,89 & 1 & 5,56 & 72 & 400 \\
\hline 3. & Seiso (Pembersihan) & 33 & 183,3 & 47 & 261,1 & 10 & 55,56 & 0 & 0,00 & 90 & 500 \\
\hline 4. & Seiketsu (Pemantapan) & 17 & 94,44 & 25 & 138,9 & 11 & 61,11 & 1 & 5,56 & 54 & 300 \\
\hline 5. & Shitsuke (Pendisiplinan) & 41 & 227,8 & 44 & 244,4 & 21 & 116,67 & 2 & 11,11 & 108 & 600 \\
\hline \multicolumn{2}{|r|}{ Total $(\%)$} & \multicolumn{2}{|c|}{$\mathbf{7 8 3 , 2 4}$} & \multicolumn{2}{|c|}{999,9} & \multicolumn{2}{|c|}{294,45} & \multicolumn{2}{|c|}{22,23} & \multicolumn{2}{|c|}{2100} \\
\hline \multicolumn{2}{|r|}{ Rata-Rata 21 item (\%) } & \multicolumn{2}{|c|}{37,30} & \multicolumn{2}{|c|}{47,61} & \multicolumn{2}{|c|}{14,02} & \multicolumn{2}{|c|}{1,06} & \multicolumn{2}{|c|}{100} \\
\hline
\end{tabular}

\section{Lampiran 2}

Tabel 1 Peringkat Jawaban Responden Berdasarkan Tingkat Respon Tertinggi

\begin{tabular}{|c|c|c|c|}
\hline Peringkat & $\begin{array}{l}\text { No. } \\
\text { Pertanyaan }\end{array}$ & Pertanyaan & $\begin{array}{c}\text { Jumlah } \\
\text { Pembobotan }\end{array}$ \\
\hline 1 & 4 & $\begin{array}{l}\text { Perlengkapan kerja yang berhubungan dengan pekerjaan } \\
\text { Bapak/Saudara sudah tertata rapi. }\end{array}$ & 67 \\
\hline 2 & 1 & $\begin{array}{l}\text { Bapak/Saudara secara teratur melakukan pemilahan berkas- } \\
\text { berkas/perlengkapan kerja antara yang diperlukan dan yang } \\
\text { kurang diperlukan. }\end{array}$ & 62 \\
\hline 3 & 3 & $\begin{array}{l}\text { Bapak/Saudara mengetahui cara-cara melakukan pemilahan } \\
\text { (menyisihkan barang yang tidak perlu) yang baik dan benar. }\end{array}$ & 61 \\
\hline 4 & 10 & Bapak/Saudara turut menjaga ruang kerja agar tetap bersih. & 61 \\
\hline 5 & 11 & $\begin{array}{l}\text { Sebelum bekerja, Bapak/Saudara selalu membersihkan } \\
\text { peralatan kerja yang setiap hari digunakan. }\end{array}$ & 60 \\
\hline 6 & 12 & $\begin{array}{l}\text { Bapak/Saudara turut menjaga agar peralatan kerja dapat } \\
\text { terhidar dari kerusakan. }\end{array}$ & 60 \\
\hline 7 & 5 & $\begin{array}{l}\text { Bapak/ Saudara tidak pernah kesulitan untuk menemukan } \\
\text { perlengkapan kerja yang diperlukan. }\end{array}$ & 59 \\
\hline 8 & 2 & $\begin{array}{l}\text { Bapak/ Saudara tidak pernah ragu untuk memisahkan } \\
\text { berkas kerja/perlengkapan kerja yang diperlukan dan } \\
\text { kurang diperlukan }\end{array}$ & 59 \\
\hline 9 & 6 & $\begin{array}{l}\text { Perlengkapan kerja (misal: kunci pas/ obeng/ cutter, dll) } \\
\text { yang biasa digunakan, disimpan di tempat khusus. }\end{array}$ & 58 \\
\hline 10 & 7 & $\begin{array}{l}\text { Perlengkapan kerja yang biasa saudara butuhkan mudah } \\
\text { didapatkan, tanpa harus lama mencari. }\end{array}$ & 58 \\
\hline 11 & 16 & $\begin{array}{l}\text { Bapak/Saudara berpartisipasi dalam mengembangkan } \\
\text { kebiasaan yang baik di tempat kerja. }\end{array}$ & 58 \\
\hline 12 & 19 & $\begin{array}{l}\text { Bapak/Saudara melakukan sesuatu yang benar sebagai } \\
\text { kebiasaan. }\end{array}$ & 58 \\
\hline 13 & 20 & $\begin{array}{l}\text { Bapak/Saudara berupaya untuk memberi contoh dalam } \\
\text { menciptakan lingkungan kerja yang tertata rapi. }\end{array}$ & 58 \\
\hline 14 & 14 & $\begin{array}{l}\text { Bapak/Saudara selalu mencari ide baru untuk memudahkan } \\
\text { mencari perlengkapan kerja yang saudara butuhkan. }\end{array}$ & 57 \\
\hline
\end{tabular}


Tabel 2 Peringkat Jawaban Responden Berdasarkan Tingkat Respon Tertinggi (Lanjutan)

\begin{tabular}{|c|c|l|c|}
\hline Peringkat & $\begin{array}{c}\text { No. } \\
\text { Pertanyaan }\end{array}$ & \multicolumn{1}{c|}{ Pertanyaan } & $\begin{array}{c}\text { Jumlah } \\
\text { Pembobotan }\end{array}$ \\
\hline 15 & 8 & $\begin{array}{l}\text { Lingkungan kerja Bapak/Saudara bersih dari sampah yang } \\
\text { berserakan (misal: kertas, puntung/abu rokok, bungkus } \\
\text { permen, dst). }\end{array}$ & 56 \\
\hline 16 & 9 & $\begin{array}{l}\text { Peralatan kerja (tools) yang digunakan serta pendukung } \\
\text { kerja Bapak/ Saudara (misal: meja, kursi, lemari) bersih } \\
\text { tidak berdebu. }\end{array}$ & 56 \\
\hline 17 & 13 & $\begin{array}{l}\text { Bapak/Saudara bersama rekan kerja saling mengingatkan } \\
\text { untuk menciptakan suasana kerja yang tertib dan nyaman. }\end{array}$ & 56 \\
\hline 18 & 17 & $\begin{array}{l}\text { Setiap peralatan kerja (tools) Bapak/Saudara disimpan dan } \\
\text { dibedakan berdasarkan pengkodean (sesuai permasalahan). }\end{array}$ & 55 \\
\hline 20 & 18 & Bapak/Saudara memahami setiap peraturan kerja. & 55 \\
\hline 21 & 15 & $\begin{array}{l}\text { Bapak/Saudara mentaati setiap bentuk peraturan kerja. } \\
\text { ke tempat asal pengambilan. }\end{array}$ & 55 \\
\hline
\end{tabular}

